\title{
Pedestrian crossing model in urban street (Case study on commercial area in Bandung)
}

\author{
Sony Sulaksono Wibowo ${ }^{1 *}$, Rian Wicaksana ${ }^{1}$ \\ ${ }^{1}$ Bandung Instute of Technology, Study Program of Civil Engineering, Bandung, Indonesia
}

\begin{abstract}
Pedestrians who cross without any crossing facilities and under mixed-traffic tend to have varying responses. The responses can be analyzed by using multiple linear regression model, with pedestrian crossing delay and pedestrian crossing speed set as response variables. This research aims to develop two pedestrian crossing models based on the condition at the midblock part of urban street, in particular commercial area and without specific crossing facilities. The two models are pedestrian crossing delay model and pedestrian crossing speed model. The affecting factors are considered in linear relationship and the multiple-linear regression models are used. The principal factor in the pedestrian crossing delay model is group size of more than 3 persons, while in the model of pedestrian crossing speed, the principal factors are number of group size and pedestrian baggage. The mean of pedestrian crossing delay was about 3 seconds while pedestrian crossing speed was about $1 \mathrm{~m} / \mathrm{s}$.
\end{abstract}

\section{Introduction}

The complexity of urban street problems generally will occur when the land-use is a center of human activities, such as market, shops, bus stop, and so forth. When this condition takes place, then there would be crowd of people around the road who can be found. In certain conditions where the roads are already crowded, vehicular and pedestrian traffic flows can be interfering on each other. This kind of chaotic traffic condition is going to be worse if there is no clear regulation about separation of car and motorcycle. This condition is well-known as mixed-traffic. Mixed-traffic is a very common case in Indonesia, particularly in Bandung. Under this chaotic condition, the pedestrians, which is varying in gender, ability, group size, or their baggage size, will tend to response freely, especially when there is no certain crossing facility.

The middle section of the road or so-called midblock area is a very vulnerable spot for the occurrence of intervention between the traffic flow and pedestrian flow, especially if the area is the commercial activity. In this condition, pedestrians often cross arbitrarily to move from one side of the road to the other side of the road through

\footnotetext{
${ }^{*}$ Corresponding author: $\underline{\text { sonyssw@gmail.com }}$
} 
traffic whose patterns and compositions may vary. This phenomenon can be called "jaywalking". When pedestrians do "jaywalking", then the varying behavior and characteristics of the crossing pedestrian may appear. The responses of the crossing pedestrian generally consist of waiting time, crossing time, gap or gap received, crossing pattern, and so forth.

Given the varying characteristics of crossing pedestrian and coupled with the mixedtraffic conditions occurring at most roads in Indonesia, particularly at Bandung, then a wide range of responses from the crossing pedestrians may appear. One thing that might be concerned for this situation is to know which pedestrian characteristics that gives a significant impact toward their responses when they cross the road. In this case, the responses will be limited to pedestrian crossing delay and pedestrian crossing speed, since time and distance can be measured and observed easily. The objective of this research is to develop pedestrian crossing model in urban street, in particular of commercial area. The model took place in the midblock area with no specific crossing facilities. In this research, two models were developed, they are model for pedestrian crossing delay and model for pedestrian crossing speed. The factors affecting to the model were considered in linear relationship. Therefore, the multiple-linear regression models were used.

\section{Literature review}

\subsection{Pedestrian characteristics}

The regulation published by department of public works stated that the characteristics of pedestrians can be divided into physical, behavioural, and psychological. The physical characteristics of pedestrian include the travel motives of pedestrians, their convenience toward the weather, the availability of public transport, and land-use of the region they are crossing at. The behavioural characteristics of pedestrians will be related to how the pedestrians are doing when they cross the road. While the psychological characteristics will be more related to the tendency about what the pedestrians desire when they cross the road, so that they will cross conveniently.

Aside from the characteristics that listed on the regulation of department of public works, there are many studies have already revealed about the similar things. For example, the studies conducted by Kuttan, et al. [1] revealed that age, gender, group size of pedestrians, and crossing pattern significantly affect their behaviour in crossing the road.

Another study related to pedestrian characteristics was conducted by Gultom [2]. This research revealed that the decision of pedestrians to cross the road was affected by their gap acceptance, age, gender, pedestrian baggage, group size, and the combination of vehicles which formed the gaps.

\subsection{Pedestrian crossing delay}

Pedestrian crossing delay is the time required by the pedestrians to wait before they resolve to cross the road. Kuttan, et al. [1] revealed that male pedestrians have tendency 
to show more hazardous crossing behaviour than female pedestrians since the waiting time of male pedestrians tend to be shorter than female pedestrians. For the group size, the same research stated that the more people involved in a crossing pedestrian group, then the more waiting time they need before crossing the road. While for the age group, there are no certain tendency which age group will wait longer than the other.

\subsection{Pedestrian crossing speed}

Pedestrian crossing speed is a distance traveled by pedestrians divided by the time they required to cross the observed lanes of the road.

Based on the study conducted by Hummer, Allen, and Milazo (1999) in Kuttan, et al. [1], generally, the pedestrian crossing speed is about $1,2 \mathrm{~m} / \mathrm{s}$. If the proportion of elderly people in a certain region is large enough (above $20 \%$ ), then the average crossing speed of pedestrians is $1,0 \mathrm{~m} / \mathrm{s}$. Based on the studies which is listed on Highway Capacity Manual (HCM) 2000 in Kuttan, et al. [1], it states that the standard pedestrian crossing speed is $1,4 \mathrm{~m} / \mathrm{s}$.

While based on the studies conducted by Montufar (2013) in Kuttan, et al. [1], the normal pedestrian crossing speed is $1,2 \mathrm{~m} / \mathrm{s}$. But, the research was not involving $40 \%$ of elderly pedestrians, $90 \%$ of disabled people, $10 \%$ of adult pedestrians (20 year-old to 64 year old pedestrians). Somehow, this research could conclude that lower designed crossing speed of pedestrian can be applied for elderly people, not only those who can walk normally, but also those who walks with walking aids.

Based on the research that was done by Montufar (2013) in Kuttan, et al. [1], then Pedestrian Crossing Control Guide, Transportation Association of Canada (TAC PCCG) modified and classified pedestrian crossing speed for facility design into these points.

- Crossing speed is $0,8 \mathrm{~m} / \mathrm{s}$, if $20 \%$ of the pedestrians are using walking aids;

- Crossing speed is $0,9 \mathrm{~m} / \mathrm{s}$, if $20 \%$ of the pedestrians are elderly;

- Crossing speed is $1,0 \mathrm{~m} / \mathrm{s}$, if all of the pedestrians are walking normally.

Knoblauch, et al. [3] conducted a study related to pedestrian crossing speed which is categorized by age and influenced by various factors and environmental conditions, such as the type of facility used. Based on the research, it was found that in the 15 th percentile, young pedestrians crossing speed is $1,25 \mathrm{~m} / \mathrm{s}$, and for elderly people, the crossing sped is only $0,97 \mathrm{~m} / \mathrm{s}$. Goh, et al. [4] also conducted a research related to pedestrian crossing speed which is categorized by age and gender. In the study, it can be concluded that the younger the age of the pedestrians, then the crossing speed will also tend to be higher. Moreover, the study also concluded that male pedestrians tend to walk faster than the female pedestrians. Kuttan, et al [1] stated that male pedestrians tend to walk faster than female pedestrian, and the research also stated that the smaller the group size of pedestrians, then the crossing speed will also tend to be faster.

\section{Research Methods}

The method used initially in this research generally consists of finding the primary data (field survey) and secondary data (literature review). The primary data needed in this research were collected in one of the road segment in Otto Iskandardinata Street, Bandung. 
The field survey was done by measuring the geometry of the road and recording the road condition. Based on this measurement, the length of the observed road segment is $100 \mathrm{~m}$, and the lane width is $3,5 \mathrm{~m}$. This field survey was conducted on Friday, April $28^{\text {th }} 2017$, and it took an hour long $(16.15-17.15)$. The time to conduct the field survey is considered as random, or without any considerations. It means that in this field survey, the surveyor does not know whether the traffic condition is on a peak hour or not. This action was taken because there are no further field survey that aims to determine the peak hour. After the data were collected, they will be used in the making of multiple linear regression model for pedestrian crossing delay and speed. The following figure is showing the location where the data were being collected.

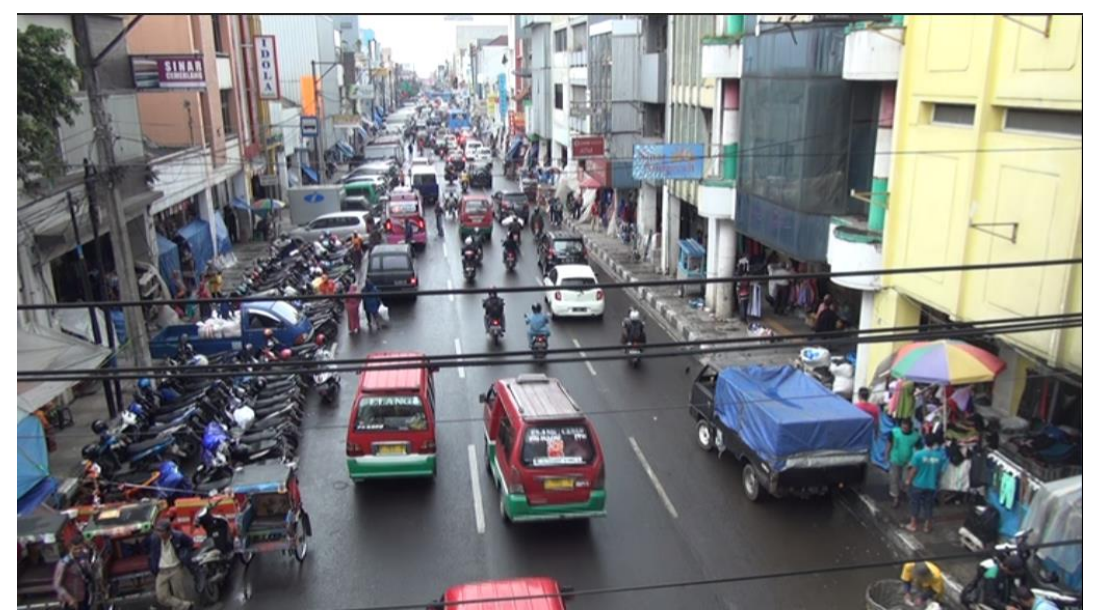

Figure.1 The study area

\section{Discussion}

After the informations and the data needed were collected, the first thing to do is making the category of the variables that are considered in this research. The pedestrian characteristics or variables of the crossing activity are shown on this following table.

Table 1. Observed variables 


\begin{tabular}{|c|c|c|c|c|}
\hline No & Variable & Type of Variable & Category & Code \\
\hline 1 & Pedestrian Crossing Delay & Continuous & Time, in seconds (s) & - \\
\hline 2 & Pedestrian Crossing Speed & Continuous & Velocity, in $(\mathrm{m} / \mathrm{s})$ & - \\
\hline \multirow{2}{*}{3} & \multirow{2}{*}{ Gender } & \multirow{2}{*}{ Discrete } & Female & 0 - Female \\
\hline & & & Male & 1 - Male \\
\hline \multirow{4}{*}{4} & \multirow{4}{*}{ Vehicle Combination } & \multirow{4}{*}{ Discrete } & Car - Car & $\begin{array}{l}0-\text { No } \\
1-\text { Yes }\end{array}$ \\
\hline & & & Car - Motorcycle & $\begin{array}{l}0 \text { - No } \\
1 \text { - Yes }\end{array}$ \\
\hline & & & Motorcycle - Car & $\begin{array}{l}0-\text { No } \\
1 \text { - Yes }\end{array}$ \\
\hline & & & Motorcycle - Motorcycle & $\begin{array}{l}0 \text { - No } \\
1 \text { - Yes }\end{array}$ \\
\hline \multirow{2}{*}{5} & \multirow{2}{*}{ Ability } & \multirow{2}{*}{ Discrete } & Vulnerable & 0 - Vulnerable \\
\hline & & & Normal & 1 - Normal \\
\hline \multirow{4}{*}{6} & \multirow{4}{*}{ Pedestrian Group Size } & \multirow{4}{*}{ Discrete } & 1 Person & $\begin{array}{l}0 \text { - No } \\
1-\text { Yes }\end{array}$ \\
\hline & & & 2 Persons & $\begin{array}{l}0 \text { - No } \\
1 \text { - Yes }\end{array}$ \\
\hline & & & 2 Persons & $\begin{array}{l}0 \text { - No } \\
1 \text { - Yes }\end{array}$ \\
\hline & & & $>3$ Persons & 0 - No \\
\hline \multirow{2}{*}{7} & \multirow{2}{*}{ Pedestrian Baggage } & \multirow{2}{*}{ Discrete } & Not Carrying & 0 - Tidak \\
\hline & & & Carrying & $1-Y a$ \\
\hline
\end{tabular}

Variables that have been mentioned in table 1 are divided into three categories, they are additional variables, predictor variables, and response variables. Table 2, 3, and 4 below will show the distribution of crossing pedestrian for each category of the mentioned variables.

Table 2. Distribution of crossing pedestrian based on predictor variables

\begin{tabular}{|c|c|c|c|c|c|}
\hline No & Variable & Category & Distribution & Percentage & Total \\
\hline \multirow{2}{*}{1} & \multirow{2}{*}{ Ability } & Vulnerable & 19 & $5,2 \%$ & \multirow{2}{*}{365} \\
\hline & & Normal & 346 & $94,8 \%$ & \\
\hline \multirow{4}{*}{2} & \multirow{4}{*}{ Pedestrian Group Size } & 1 Person & 224 & $61,4 \%$ & \multirow{4}{*}{365} \\
\hline & & 2 Persons & 94 & $25,8 \%$ & \\
\hline & & 3 Persons & 21 & $5,8 \%$ & \\
\hline & & $>3$ Persons & 26 & $7,1 \%$ & \\
\hline \multirow{2}{*}{3} & \multirow{2}{*}{ Gender } & Female & 96 & $26,3 \%$ & \multirow{2}{*}{365} \\
\hline & & Male & 269 & $73,7 \%$ & \\
\hline \multirow{4}{*}{4} & \multirow{4}{*}{ Vaehicle Combination } & Car - Car & 138 & $37,8 \%$ & \multirow{4}{*}{365} \\
\hline & & Car - Motorcycle & 92 & $25,2 \%$ & \\
\hline & & Motorcycle - Car & 70 & $19,2 \%$ & \\
\hline & & Motorcycle-Motorcycle & 65 & $17,8 \%$ & \\
\hline \multirow{2}{*}{5} & \multirow{2}{*}{ Pedestrian Baggage } & Carrying & 66 & $18,1 \%$ & \multirow{2}{*}{365} \\
\hline & & Not Carrying & 299 & $81,9 \%$ & \\
\hline
\end{tabular}


Table 3. Distribution of crossing pedestrian based on response variables

\begin{tabular}{|c|c|c|c|c|c|}
\hline No & Variable & Category & Distribution & Percentage & Total \\
\hline \multirow{10}{*}{1} & \multirow{10}{*}{ Pedestrian Crossing Delay } & $0,1 \mathrm{~s}-2,2 \mathrm{~s}$ & 121 & $33,2 \%$ & \multirow{10}{*}{365} \\
\hline & & $2,2 \mathrm{~s}-4,3 \mathrm{~s}$ & 127 & $34,8 \%$ & \\
\hline & & $4,3 \mathrm{~s}-6,3 \mathrm{~s}$ & 55 & $15,1 \%$ & \\
\hline & & $6,3 \mathrm{~s}-8,4 \mathrm{~s}$ & 26 & $7,1 \%$ & \\
\hline & & $8,4 \mathrm{~s}-10,4 \mathrm{~s}$ & 9 & $2,5 \%$ & \\
\hline & & $10,4 \mathrm{~s}-12,5 \mathrm{~s}$ & 11 & $3,0 \%$ & \\
\hline & & $12,5 \mathrm{~s}-14,6 \mathrm{~s}$ & 5 & $1,4 \%$ & \\
\hline & & $14,6 s-16,6 s$ & 7 & $1,9 \%$ & \\
\hline & & $16,6 \mathrm{~s}-18,7 \mathrm{~s}$ & 0 & $0,0 \%$ & \\
\hline & & $18,7 \mathrm{~s}-20,8 \mathrm{~s}$ & 4 & $1,1 \%$ & \\
\hline \multirow{10}{*}{2} & \multirow{10}{*}{ Pedestrian Crossing Speed } & $0,4 \mathrm{~m} / \mathrm{s}-0,7 \mathrm{~m} / \mathrm{s}$ & 46 & $12,6 \%$ & \multirow{10}{*}{365} \\
\hline & & $0,7 \mathrm{~m} / \mathrm{s}-1,0 \mathrm{~m} / \mathrm{s}$ & 125 & $34,2 \%$ & \\
\hline & & $1,0 \mathrm{~m} / \mathrm{s}-1,3 \mathrm{~m} / \mathrm{s}$ & 125 & $34,2 \%$ & \\
\hline & & $1,3 \mathrm{~m} / \mathrm{s}-1,6 \mathrm{~m} / \mathrm{s}$ & 53 & $14,5 \%$ & \\
\hline & & $1,6 \mathrm{~m} / \mathrm{s}-1,9 \mathrm{~m} / \mathrm{s}$ & 8 & $2,2 \%$ & \\
\hline & & $1,9 \mathrm{~m} / \mathrm{s}-2,2 \mathrm{~m} / \mathrm{s}$ & 3 & $0,8 \%$ & \\
\hline & & $2,2 \mathrm{~m} / \mathrm{s}-2,5 \mathrm{~m} / \mathrm{s}$ & 3 & $0,8 \%$ & \\
\hline & & $2,5 \mathrm{~m} / \mathrm{s}-2,8 \mathrm{~m} / \mathrm{s}$ & 1 & $0,3 \%$ & \\
\hline & & $2,8 \mathrm{~m} / \mathrm{s}-3,1 \mathrm{~m} / \mathrm{s}$ & 0 & $0,0 \%$ & \\
\hline & & $3,1 \mathrm{~m} / \mathrm{s}-3,4 \mathrm{~m} / \mathrm{s}$ & 1 & $0,3 \%$ & \\
\hline
\end{tabular}

\subsection{Outlier Test}

The outlier test aims to investigate the extreme values of a data set. This test will be done in two out of three known methods. They are data standardization and box plot. From these two methods, the result will be taken from the box plot method. The outlier test is only available for the continuous variables. In this case, the continuous variables is only existing on the response variables category (pedestrian crossing speed and pedestrian crossing delay). This outlier test will show the amount of extereme data. Afterward, the extreme data shown by this test will be eliminated so that a new data set with less extreme values may appear. This test will be done in repetition until the extreme values could not be found in the data set. After this test is being applied on response variables, then a new data set of pedestrian crossing delay and pedestrian crossing speed with no extreme value can be exposed in the following tables. 
Table 4. Distribution of crossing pedestrian based on delay time (without outlier)

\begin{tabular}{|c|c|c|c|c|c|}
\hline No & Variable & Category & Distribution & Percentage & Total \\
\hline \multirow{10}{*}{1} & \multirow{10}{*}{ Pedestrian Crossing Delay } & $0,1 \mathrm{~s}-0,9 \mathrm{~s}$ & 18 & $5,6 \%$ & \multirow{10}{*}{323} \\
\hline & & $0,9 \mathrm{~s}-1,7 \mathrm{~s}$ & 69 & $21,4 \%$ & \\
\hline & & $1,7 \mathrm{~s}-2,4 \mathrm{~s}$ & 43 & $13,3 \%$ & \\
\hline & & $2,4 \mathrm{~s}-3,2 \mathrm{~s}$ & 53 & $16,4 \%$ & \\
\hline & & $3,2 \mathrm{~s}-3,9 \mathrm{~s}$ & 55 & $17,0 \%$ & \\
\hline & & $3,9 s-4,7 s$ & 33 & $10,2 \%$ & \\
\hline & & $4,7 \mathrm{~s}-5,4 \mathrm{~s}$ & 17 & $5,3 \%$ & \\
\hline & & $5,4 s-6,2 s$ & 11 & $3,4 \%$ & \\
\hline & & $6,2 \mathrm{~s}-6,9 \mathrm{~s}$ & 12 & $3,7 \%$ & \\
\hline & & $6,9 \mathrm{~s}-7,7 \mathrm{~s}$ & 12 & $3,7 \%$ & \\
\hline
\end{tabular}

Table 5. Distribution of Crossing Pedestrian Based on Crossing Speed (Without Outlier)

\begin{tabular}{|c|c|c|c|c|c|}
\hline No & Variable & Category & Distribution & Percentage & Total \\
\hline \multirow{10}{*}{1} & \multirow{10}{*}{ Pedestrian Crossing Speed } & $0,4 \mathrm{~m} / \mathrm{s}-0,5 \mathrm{~m} / \mathrm{s}$ & 10 & $2,8 \%$ & \multirow{10}{*}{353} \\
\hline & & $0,5 \mathrm{~m} / \mathrm{s}-0,7 \mathrm{~m} / \mathrm{s}$ & 22 & $6,2 \%$ & \\
\hline & & $0,7 \mathrm{~m} / \mathrm{s}-0,8 \mathrm{~m} / \mathrm{s}$ & 49 & $13,9 \%$ & \\
\hline & & $0,8 \mathrm{~m} / \mathrm{s}-0,9 \mathrm{~m} / \mathrm{s}$ & 54 & $15,3 \%$ & \\
\hline & & $0,9 \mathrm{~m} / \mathrm{s}-1,1 \mathrm{~m} / \mathrm{s}$ & 79 & $22,4 \%$ & \\
\hline & & $1,1 \mathrm{~m} / \mathrm{s}-1,2 \mathrm{~m} / \mathrm{s}$ & 57 & $16,1 \%$ & \\
\hline & & $1,2 \mathrm{~m} / \mathrm{s}-1,3 \mathrm{~m} / \mathrm{s}$ & 35 & $9,9 \%$ & \\
\hline & & $1,3 \mathrm{~m} / \mathrm{s}-1,4 \mathrm{~m} / \mathrm{s}$ & 28 & $7,9 \%$ & \\
\hline & & $1,4 \mathrm{~m} / \mathrm{s}-1,6 \mathrm{~m} / \mathrm{s}$ & 14 & $4,0 \%$ & \\
\hline & & $1,6 \mathrm{~m} / \mathrm{s}-1,8 \mathrm{~m} / \mathrm{s}$ & 5 & $1,4 \%$ & \\
\hline
\end{tabular}

\subsection{Formulation of Regression Model}

In order to make a good multiple linear regression model, the insignificant predictor variables must be eliminated. This research will use three methods in order to eliminate those insignificant variabels. They are the elimination based on the least coefficient value (known as stepwise II), elimination based on the least p-value, and elimination based on the "backward" feature in SPSS.

Every methods will produce a different set of parameter. The difference of applied method will make the formed model is being different as well. Rules of a good multiple linear regression model recites that the model have to involve as many predictor variables as possible. Moreover, every coefficients in the model have to follow the plus and minus sign (+/-) that already expected before. Table 7 and table 8 below shows the mutiple linear regression model formed by different methods. 
Table 6. Model of pedestrian crossing delay

\begin{tabular}{|c|c|c|c|c|c|c|c|c|c|}
\hline \multirow[b]{2}{*}{ No } & \multirow[b]{2}{*}{ Parameter } & \multirow[b]{2}{*}{$\begin{array}{l}\text { Expected } \\
\text { Sign }\end{array}$} & \multirow[b]{2}{*}{ Variables } & \multirow{2}{*}{\multicolumn{2}{|c|}{$\begin{array}{c}\text { Method } 1 \\
\text { Coefficient } \\
\text { (p-value) }\end{array}$}} & \multirow{2}{*}{\multicolumn{2}{|c|}{$\begin{array}{c}\text { Method } 2 \\
\text { Coefficient } \\
\text { (p-value) }\end{array}$}} & \multirow{2}{*}{\multicolumn{2}{|c|}{$\begin{array}{c}\text { Method } 3 \\
\text { Coefficient } \\
\text { (p-value) }\end{array}$}} \\
\hline & & & & & & & & & \\
\hline 1 & Intercept & $(+/-)$ & $\mathrm{C}$ & 3,12 & $(0,000)$ & 2,97 & $(0,000)$ & 2,97 & $(0,000)$ \\
\hline 2 & Gender & $(-)$ & $X_{1}$ & 0,02 & $(0,925)$ & & & & \\
\hline 3 & Car - Car & $(+)$ & $\mathrm{X}_{2}$ & & & & & & \\
\hline 4 & Car - Motorcycle & $(+)$ & $\mathrm{X}_{3}$ & 0,18 & $(0,468)$ & & & & \\
\hline 5 & Motorcycle - Car & $(+)$ & $\mathrm{X}_{4}$ & 0,27 & $(0,325)$ & & & & \\
\hline 6 & Motorcycle - Motorcycle & $(+)$ & $\mathrm{X}_{5}$ & 0,05 & $(0,868)$ & & & & \\
\hline 7 & Ability & $(-)$ & $X_{6}$ & $-0,31$ & $(0,591)$ & & & & \\
\hline 8 & Group Size of 1 Person & $(-)$ & $\mathrm{X}_{7}$ & & & & & & \\
\hline 9 & Group Size of 2 Persons & $(+)$ & $\mathrm{X}_{8}$ & 0,21 & $(0,371)$ & & & & \\
\hline 10 & Group Size of 3 Persons & $(+)$ & $\mathrm{X}_{9}$ & 0,44 & $(0,415)$ & & & & \\
\hline 11 & Group Size of $>3$ Persons & $(+)$ & $\mathrm{X}_{10}$ & 1,19 & $(0,004)$ & 1,23 & $(0,001)$ & 1,23 & $(0,001)$ \\
\hline 12 & Pedestrian Baggage & $(-)$ & $X_{11}$ & $-0,21$ & $(0,408)$ & & & & \\
\hline \multicolumn{4}{|c|}{ Significance Value 0} & \multicolumn{2}{|c|}{0,110} & \multicolumn{2}{|c|}{0,001} & \multicolumn{2}{|c|}{0,001} \\
\hline
\end{tabular}

Table 7. Model of pedestrian crossing speed

\begin{tabular}{|c|c|c|c|c|c|c|c|c|c|}
\hline \multirow{3}{*}{$\begin{array}{l}\text { No } \\
1\end{array}$} & \multirow[b]{2}{*}{ Parameter } & \multirow{3}{*}{$\begin{array}{c}\text { Expected } \\
\text { Sign } \\
(+/-)\end{array}$} & \multirow{3}{*}{$\begin{array}{c}\text { Variables } \\
\mathrm{C}\end{array}$} & \multirow{2}{*}{\multicolumn{2}{|c|}{$\begin{array}{l}\text { Method } 1 \\
\text { Coefficient } \\
\text { (p-value) }\end{array}$}} & \multirow{2}{*}{\multicolumn{2}{|c|}{$\begin{array}{c}\text { Method 2 } \\
\text { Coefficient } \\
(p \text {-value })\end{array}$}} & \multirow{2}{*}{\multicolumn{2}{|c|}{$\begin{array}{c}\text { Method } \mathbf{3} \\
\text { Coefficient } \\
(p \text {-value })\end{array}$}} \\
\hline & & & & & & & & & \\
\hline & Intercept & & & 1,00 & $(0,000)$ & 1,06 & $(0,000)$ & 1,06 & $(0,000)$ \\
\hline 2 & Gender & $(-)$ & $X_{1}$ & 0,03 & $(0,359)$ & & & & \\
\hline 3 & Car - Car & $(+)$ & $\mathrm{X}_{2}$ & & & & & & \\
\hline 4 & Car - Motorcycle & $(+)$ & $X_{3}$ & $-0,01$ & $(0,853)$ & & & & \\
\hline 5 & Motorcycle - Car & $(+)$ & $X_{4}$ & $-0,06$ & $(0,117)$ & & & & \\
\hline 6 & Motorcycle - Motorcycle & $(+)$ & $\mathrm{X}_{5}$ & $-0,04$ & $(0,309)$ & & & & \\
\hline 7 & Ability & $(-)$ & $\mathrm{X}_{6}$ & 0,05 & $(0,429)$ & & & & \\
\hline 8 & Group Size of 1 Person & $(-)$ & $\mathrm{X}_{7}$ & & & & & & \\
\hline 9 & Group Size of 2 Persons & $(+)$ & $\mathrm{X}_{8}$ & $-0,06$ & $(0,068)$ & $-0,07$ & $(0,019)$ & $-0,07$ & $(0,019)$ \\
\hline 10 & Group Size of 3 Persons & $(+)$ & $\mathrm{X}_{9}$ & $-0,13$ & $(0,054)$ & $-0,15$ & $(0,012)$ & $-0,15$ & $(0,012)$ \\
\hline 11 & Group Size of $>3$ Persons & $(+)$ & $\mathrm{X}_{10}$ & $-0,14$ & $(0,013)$ & $-0,17$ & $(0,001)$ & $-0,17$ & $(0,001)$ \\
\hline 12 & Pedestrian Baggage & $(-)$ & $X_{11}$ & $-0,10$ & $(0,006)$ & $-0,09$ & $(0,010)$ & $-0,09$ & $(0,010)$ \\
\hline \multicolumn{4}{|c|}{ Significance Value of F-Test } & \multicolumn{2}{|c|}{0,003} & \multicolumn{2}{|c|}{0,000} & \multicolumn{2}{|c|}{0,000} \\
\hline
\end{tabular}

\subsection{Analysis of Model Selection}

For the pedestrian crossing delay model, then the selected model is the one formed by method 3 or method 2. This model will be selected into the next step of analysis is because, first, despite the predictor variable involved in this model is merely one, that is pedestrian group size of more than 3 persons, the predictor variable has a strong tendency to become the involved variables in model. This case is indicated by the significant number or $\mathrm{p}$-value of partial test that pedestrian group size of more than 3 persons has fulfilled the predefined requirement $(<0,1)$. Second, the model formed by these methods has fulfilled the requirement of simultaneous test $(<0,1)$ as well. Third, the sign following the coefficients of pedestrian crossing delay model just match with the expected sign. This model shows that the most influencing characteristics at 
determining pedestrian crossing delay in the observed road is group size of more than 3 persons. This case indicates that people who cross the road in a group of more than 3 people, tend to be waiting for the readiness of each other to cross the road. Readiness, in this case is to determine the desired combination of vehicles, or to find the appropriate gap between vehicles, which is suitable for the crossing pedestrian in a group of more than 3 persons.

The same methods (2 and 3 ) is selected again for the model of pedestrian crossing speed due to the same reason as it was selected in pedestrian crossing delay model. Moreover, the $\mathrm{p}$-value of model formed by these methods is even better than $\mathrm{p}$-value of model formed by method 1 (the more $\mathrm{p}$-value getting close to 0 , then the variables chance to get involved in the model are higher). Beside, the sign following the coefficients of pedestrian crossing speed model just match with the expected sign. This model shows that the most-influencing characteristics at determining pedestrian crossing speed are group size of more than 1 person, and pedestrian baggage. The reasons why pedestrians who walk in a group tend to be slower than those who do not are they have to adjust for each other physical and mental skill. It means that one member of the crossing group have to adjust his walking speed with another, usually the slowest pedestrian. The more member involved in this group, then the group walking speed tends to be slower. It is due to the increasing difficulty to adjust physical skill to the weakest pedestrian (walking speed, etc.). This statement is being backed up by the coefficients of the model which is increasing along the number of pedestrian getting involved in a crossing group. Beside the group size of pedestrian, the other significant characteristic are pedestrian baggage. In this research, baggage is limited to trolley, large goods carried on back, or baby holding. These kind of pedestrian baggage is considered as an obstruction to the sight distance and limiting the moving space of pedestrian. In general, the pedestrian who carries this kind of baggage tends to be more careful so that the baggage does not fall in the middle of the road. Therefore, their crossing speed becomes slower. There was some chances for pedestrian who walks in a group also carrying those kind of pedestrian baggage. If these two conditions meet, then the crossing speed would be much slower.

\section{Conclusions}

The multiple linear regression model for pedestrian crossing delay is $Y=2,97+1,23 X_{10}$, the model shows that the most influencing characteristic for determining pedestrian crossing delay is $X_{10}$ or group size of more than 3 persons. This model can be applied by making the probability of the conditions that may appear, and determine the proportion of each conditions, so that the mean value of pedestrian crossing delay, which is going to be used as design criteria can be obtained. Based on the model, the mean value of pedestrian crossing delay at the observed road segment of Otto Iskandardinata Street, Bandung is 3,054 s.

The multiple linear regression model for pedestrian crossing speed is $Y=1,06-0,07 X_{8}-0,15 X_{9}-0,17 X_{10}-0,09 X_{11}$, unfortunately, this equation is not valid for a group of crossing pedestrian because of the group size variables cannot work simultaneously. So, the equation will be divided into three conditions 
- $\quad$ For pedestrian group size of 2 persons

$$
Y=1,06-0,07 X_{8}-0,09 X_{11}
$$

- $\quad$ For pedestrian group size of 3 persons

$$
Y=1,06-0,15 X_{9}-0,09 X_{11}
$$

- $\quad$ For pedestrian group size of more than 3 persons

$$
Y=1,06-0,17 X_{10}-0,09 X_{11}
$$

where,

$\begin{array}{ll}X_{8} & =\text { Group size consists of } 2 \text { persons } \\ X_{9} & =\text { Group size consists of } 3 \text { persons } \\ X_{10} & =\text { Group size consists of more than } 3 \text { persons } \\ X_{11} & =\text { Pedestrian Baggage }\end{array}$

Based on the model that mentioned above, then the mean value of pedestrian crossing speed at the observed road segment in Otto Iskandardinata Street, Bandung is $1,005 \mathrm{~m} / \mathrm{s}$.

\section{Acknowledgements}

Most of data and analysis was already presented in second author's final paper (unpublished) in Civil Engineering Program in Bandung Institute of Technology under first author supervision. More detail work can be obtained in university's electronic library.

\section{References}

1. Kuttan, Mannu O, et. al. Analysis and Modelling of Pedestrian Road Crossing Pattern on Urban Undivided Roads in Mixed Traffic in Proceedings of the $12^{\text {th }}$ International Conference on Transportation Planning, and Implementation Methodologies for Developing Countries, December 2016, IIT Bombay, India. . (2016)

2. Gultom, Hansen Samuel Arberto. x Model Perilaku Pengambilan Keputusan untuk Menyeberang Jalan di Daerah Mid-block. Bandung: Institut Teknologi Bandung, pp. 23 - 61. Thesis for master's degree in highway engineering and development, Institut Teknologi Bandung. (2012)

3. Knoblauch, Richard, et. al. Field Studies of Pedestrian Waking Speed and Start-up Time. Transportation Research Board, Volume 1538, ISSN 0361-1981. (1996)

4. Goh, Boon Hoe, et. al. Pedestrian Crossing Speed: The Case of Malaysia. International Journal For Transport and Traffic Engineering, Volume 2, pp. 323-332, ISSN 2217544X. (2012)

5. Agresti, Alanx. An Introduction to Categorical Data Analysis. USA: Wiley, pp. 2-3. (2009) 
6. Chutani, Chirag. L.O.S. For Pedestrian at Uncontrolled Mid-Block Crossings. New Delhi: Transport Planning Department, School of Planning and Architecture.

7. Hidayat, Erwin. Pemilihan Fasilitas Penyeberangan Berdasarkan Gap Kritis (Studi Kasus Jalan Dharmawangsa, Surabaya). Widyariset, Volume 15 No.3, pp. 585-592. (2012)

8. Munder, S., dan D.M Gavrilla. An Experimental Study on Pedestrian Classification. IEEE Transactions on Pattern Analysis and Machine Intelligence, Volume 28, pp 1863 1868, ISSN 0162-8828.(2006)

9. Ontario Traffic Manual. Pedestrian Crossing Treatment. Ontario: Ministry of Transportation, Ontario, pp. 17-18. (2014)

10. Soehartono. Analisis Sarana Penyeberangan dan Perilaku Pejalan Kaki Menyeberang Di Ruas Jalan Prof. Sudarto, SH Kecamatan Banyumanik Kota Semarang (Jurnal). Semarang. Repository for bachelor's degree in building engineering education, Universitas Negeri Semarang. (2013)

11. Utomo, Fajar. Analisis Pola Pergerakan Penyeberangan Jalan di Lingkungan Sekolah Studi Kasus SDN 01/02 Cibubur - Ciracas, Jakarta Timur. Depok: Universitas Indonesia, pp. 5. Thesis for bachelor's degree in civil engineering, Universitas Indonesia. (2011) 